\title{
Body of evidence: forensic use of baseline health assessments to convict wildlife poachers
}

\author{
Brian T. Henen, Margaretha D. Hofmeyr and Ernst H. W. Baard
}

\begin{abstract}
Context. Given the immense impact of wildlife trade, disease and repatriations on populations, health assessments can provide powerful forensic material to help convict wildlife poachers and minimise risks of releasing unhealthy wildlife.

Aims. We aimed to use reference ranges to assess the health of confiscated tortoises, to illustrate forensic application of these ranges, and to advance analyses for future applications.

Methods. We used analyses of variance (ANOVA) and covariance (ANCOVA), and composite indices, to compare wild and confiscate tortoise body condition, haematocrit and haemoglobin concentration of males and females of three tortoise species. Subsequently, we used multivariate statistics (e.g. discriminant analyses) to evaluate the relative importance of species, sex and group (wild or confiscate) on tortoise condition and haematology.

Key results. Our initial statistical tests demonstrated, at $\mathrm{P}<0.05$ to $\mathrm{P}<0.0005$, that confiscate body condition and haematology were compromised compared with that of wild tortoises. Subsequently, discriminant analyses strongly discriminated between most wild and confiscate groups $(\mathrm{P}<0.0001)$, correctly classified individual health as wild or confiscate $80-90 \%$ of the time, indicated that species and sex effects were stronger than was the wild-confiscate category, and provided discriminant functions for use on other taxa and studies.

Conclusions. The health assessments discriminated well between wild and confiscate tortoises. The results had considerable forensic value, being relevant, quickly generated using portable field equipment, reliable, accurate, easy to explain and convey in terms of likelihood in a court of law, synergistically consistent among variables and groups, a strong rebuttal to the poachers' specific statements, and consistent with other types of evidence. Multivariate analyses were consistent with, and more prudent and powerful than, the original statistical analyses. Discriminant functions can be applied in future studies and on other chelonian species, and should be developed for other wildlife species.

Implications. Reference ranges provide considerable value for forensics, diagnostics and treatment. Given the disease risks resulting from the massive scale of wildlife trade and release, reference ranges should be developed for more species.
\end{abstract}




\section{Introduction}

The annual illegal trade of endangered species exceeds 30 billion dollars and is linked to organised crime, illicit drug and arms sales, and terrorism (Wyler and Sheikh 2008; EUROPOL 2011). Consequently, agencies are increasingly monitoring the international trade of endangered species (e.g. TRAFFIC 2004; Fidenci and Maran 2009; Leuteritz and Weissgold 2013) and investing in forensic networks, methods and technology (among others, Cooper et al. 2009; Ogden et al. 2009; TRAFFIC 2010) to catch and prosecute poachers and traders. Often, confiscated wildlife are diseased, desiccated and emaciated, and suffer high mortality in transit (Bailey et al. 2000; TRAFFIC 2004; Ward et al. 2012) because poacher profits significantly outweigh poacher concern for wildlife welfare. Also, wildlife poaching can extirpate populations (Fidenci and Maran 2009; Leuteritz and Weissgold 2013) and releasing unhealthy wildlife may introduce disease to naive populations and communities (Bailey et al. 2000; Real et al. 2000; Sainsbury and Vaughan-Higgins 2012). Thus, it is important to establish reference ranges for healthy wildlife, evaluate the health of native populations, and screen the health of imported and confiscated wildlife.

Reference values from health assessments can inform a variety of evaluations, from physiology, disease etymology and epidemiology (Christopher et al. 1999; Swimmer 2000; Flint et al. 2010; Ward et al. 2012) to species recovery plans (United States Fish and Wildlife Service 1994) and translocation risk assessments (Sainsbury and Vaughan-Higgins 2012); however, we lack reference values for most species (Atkins et al. 2010). We had just measured reference values for two tortoise species, Homopus areolatus and Psammobates geometricus (petitioned as Critically Endangered), and were assessing the health of a third species, Chersina angulata, when 54 tortoises of these three species were confiscated from poachers attempting transit from KwaZulu-Natal Province, South Africa, to Mozambique. The species were easy to identify as non-native to KwaZulu-Natal or Mozambique, and we also had the unique opportunity to use season-, species- and sexspecific reference ranges to evaluate the poachers' claims that they had just recently collected the tortoises from the wild. Our quick health assessments were used forensically and rebutted their claims, helping convict the poachers who received '... the heftiest fine in the history of the Cape Nature Conservation Ordinance' (Western Cape Nature Conservation Board 2001). We also provided our health assessments to zoo staff for subsequent care of the confiscates.

Here, we report how simple, proactive health assessments had several forensic features critical to rebuttal arguments (Cooper et al. 2009; Ogden et al. 2009), especially the strong statistical discrimination between wild and confiscate health. Body mass, carapace length, haematocrit and haemoglobin concentration were compared between wild and confiscate adult tortoises using analyses of variance (ANOVA) or covariance (ANCOVA). We also calculated composite indices to rate the health of each adult confiscate. Subsequent to the conviction, there was sufficient time to perform more powerful and prudent data analyses, including multivariate ANCOVA (MANCOVA), multiple 
regression (MR), discriminant analysis (DA) and factor analysis (FA), that should improve future forensic application.

\section{Materials and methods \\ Animal sampling schedule}

On 26 January 2001, 16 angulate tortoises (C. angulata), 23 geometric tortoises (P. geometricus) and 15 common padlopers (H. areolatus) were confiscated in KwaZulu-Natal and moved on 6 February to the Tygerberg Zoo, Cape Town, Western Cape Province, South Africa. There, we weighed, measured and bled 53 of them on 7 February and completed physical exams on 8 and 9 February. We did not bleed the smallest, $37 \mathrm{~g}$, P. geometricus. Since reference values were collected on adults, and juvenile confiscates were few, we excluded juvenile confiscate data and the data for one adult P. geometricus, because its blood sample clotted. Consequently, we analysed body size and haematological data for $11 \mathrm{C}$. angulata (four males and seven females; 200-750 g), 21 P. geometricus (15 males and six females; 170-575 g) and $13 \mathrm{H}$. areolatus (six males and seven females; 125-266 g). All confiscates were provided water immediately following physical examinations and six (45\%) H. areolatus quickly submerged their heads and swallowed water for $15^{-180 \mathrm{~s} \text {. }}$

We had reference health assessments, using the same equipment, for the same species, groups (adult males and females), dry season and region where the confiscates originated (Western Cape Province, South Africa). Health was assessed for adult C. angulata (males $\mathrm{n}=16$; females $\mathrm{n}=18$ ) from 29 January to 1 February 2001. Health had been assessed earlier in the dry season, 11-18 December 2000, for wild adult P. geometricus (males, $\mathrm{n}=8$; females, $\mathrm{n}=9$ ) and $\mathrm{H}$. areolatus (males, $\mathrm{n}=9$; females, $\mathrm{n}=10$ ).

\section{Haematology and body size}

Immediately before sampling blood, we weighed each tortoise to $\pm 0.5 \mathrm{~g}$ (C. angulata) or $\pm 0.1 \mathrm{~g}$ (P. geometricus and $\mathrm{H}$. areolatus) on portable electronic balances (O'Haus Corporation, Florham Park, New Jersey, USA). We sampled whole blood, $<0.5 \%$ of body mass (minimally 50 mL), via sterile jugular venipuncture (Jacobson et al. 1992; Christopher et al. 1999) and immediately measured haematocrit (Hct or packed cell volume, \%) on centrifuged aliquants $(10 \mathrm{~min}, 2200 \mathrm{~g}$ on a Force 7 microcentrifuge, Denver Instrument, Denver, Colorado, USA). The remaining blood was kept on ice and we measured $\mathbf{- 1}$ haemoglobin concentration ( $\mathrm{Hb}, \mathrm{g} \mathrm{dL}$ ) within $16 \mathrm{~h}$ of sampling, on a BMS portable haemoglobinmeter (cyanmethaemoglobin method; Omron Healthcare, Vernon, Illinois, USA).

For each tortoise, we used stainless-steel vernier calipers (Mitutoyo, Tokyo, Japan) to measure straight carapace length $(\mathrm{CL} \pm 0.1 \mathrm{~mm})$ as the horizontal distance between the distal edges of the nuchal and supracaudal scutes. During physical exams of the confiscates (Christopher et al. 1999; Berry and Christopher 2001), we observed no overt trauma or signs of disease (e.g. rhinitis), so we do not include those data. 


\section{Statistics}

Our initial statistical analyses included Student's t-tests, one- or two-way ANOVA, leastsquares regression and ANCOVA. SigmaPlot 11.0 (Systat Software, San Jose, California, USA) was used for these tests, except ANCOVA were performed in spreadsheets using formulae from Zar (1999). We report analyses using $\log _{10}$ body mass ( $\log _{10} \quad M$ ) and $\log _{10}$ carapace length $\left(\log _{10} \mathrm{CL}\right)$ because transformed data were related theoretically (allometry) and linearly, and compared with untransformed data, they consistently provided stronger statistical results (e.g. F- and P-values) and resolution among variables. Our ANCOVA were consistent with, and more readily conveyed visible detail than did MANCOVA, so we present ANCOVA and MANCOVA results. For each sex of each species, we tested whether ANCOVA slopes were equal between wild (W) and confiscate (C) groups (Zar 1999). If regression slopes were equal, we tested regressions for equal elevations. Different elevations suggested body-condition differences among groups.

For each individual confiscate, we calculated a composite index by using individual deviations from reference values (body mass, Hct and $\mathrm{Hb}$ ). The body mass component was derived from deviations from the $\log _{10} \quad M-\log _{10} \quad$ CL regressions for wild reference animals, with +2 and +1 scores representing confiscate masses higher than the upper $95 \%$ prediction and confidence interval limits, respectively, -2 and -1 scores for confiscate masses smaller than the lower prediction and confidence limits, respectively, and $\mathrm{o}$ for confiscate masses within the 95\% CI (confidence interval). Similar scores from +2 to -2 were assigned for confiscate deviations exceeding the $99 \%$ and $95 \%$ CI for reference Hct and $\mathrm{Hb}$, and zero falling within the $95 \% \mathrm{CI}$. The composite index equalled the sum of the three scores.

Our sample of wild $(n=70)$ and confiscate $(n=45)$ tortoises was small, so we did not perform split-sample multivariate analyses (Hair et al. 1998; Spicer 2005). We considered the multivariate analyses as exploratory, and completed them with Statistica 10 (StatSoft, Tulsa, Oklahoma, USA). For multivariate tests, we used multiple regression and MANCOVA, with $\log _{10}$ CL as the covariate, to test for effects of species, sex and group (W and C) on $\log _{10} \quad \mathrm{M}$, Hct and Hb. Student-Newman-Keuls (SNK) tests $(\mathrm{P}<0.05)$ were used after MANCOVA, to elaborate details of the main effects and significant interactions.

Discriminant analysis (DA) was used to evaluate how well the four variables discriminated between $\mathrm{W}$ and $\mathrm{C}$ groups, with species and sex as categorical predictors. We present the most consistent and fewest-variable results from forward- and backward-stepwise, and forward-entry and reverse-removal, discriminant analyses, using $\mathrm{P}<0.05$ for the F-toremove and F-to-enter criteria. DA was also used to explore discriminatory power among the 12 groups (i.e. the 12 species, sex and $\mathrm{W}-\mathrm{C}$ combinations). Discriminant functions were evaluated using Wilk's lambda and canonical $\mathrm{R}$ coefficients, and their corresponding $\mathrm{c}^{2}$ and F-values. F-tests were used to evaluate differences $(\mathrm{P} \leq 0.05)$ for squared 
Mahalanobis distances $\left(\mathrm{D}^{2}\right)$ between centroids for two group (W-C) contrasts and among 12 group centroids.

We evaluated classification success of the discriminant functions using the hit ratio, i.e. the percentage of all animals correctly classified, Press's Q-statistic, and the maximum chance (MC) ratio. If the MC ratio, the ratio of the hit ratio to the largest group's percentage of total sample size, was $>1.25$, the discriminant function was better than chance classifications (Hair et al. 1998). The raw coefficients of the discriminant functions are presented for future use. We also listed the rank of the standardised coefficients to indicate the strength of the variables contributing to the functions, and the rank of the structure coefficients to indicate the correlation between the independent variables and discriminant function.

In the factor analysis, we used principal components extraction, and Varimax normalised rotation of the axes, to quantify patterns among the independent variables, $\log _{10}$ M, $\log _{10}$ CL, Hct and Hb (Hair et al. 1998; Spicer 2005).

\section{Results}

\section{Body condition}

Confiscates (C) had poorer body condition (ANCOVA, Figs 1-3), that is, lower regression elevations, than did their wild (W) counterparts in females of each species, and in male P. geometricus (Fig. 2a). MANCOVA also detected differences between wild and confiscate animals (W-C, Table 1). For male C. angulata, the regression was not statistically lower (only $6.5 \mathrm{~g}$ or $\sim 1 \%$ of the body mass) for confiscates than that for wild males (Fig. 1a). For confiscate male $\mathrm{H}$. areolatus, there were too few data for a significant regression, whereas all confiscate points fell below the regression line for the wild males (Fig. 3a), and five and four points fell below the lower $95 \%$ confidence and prediction limits, respectively, of the wild males (Fig. 3). 


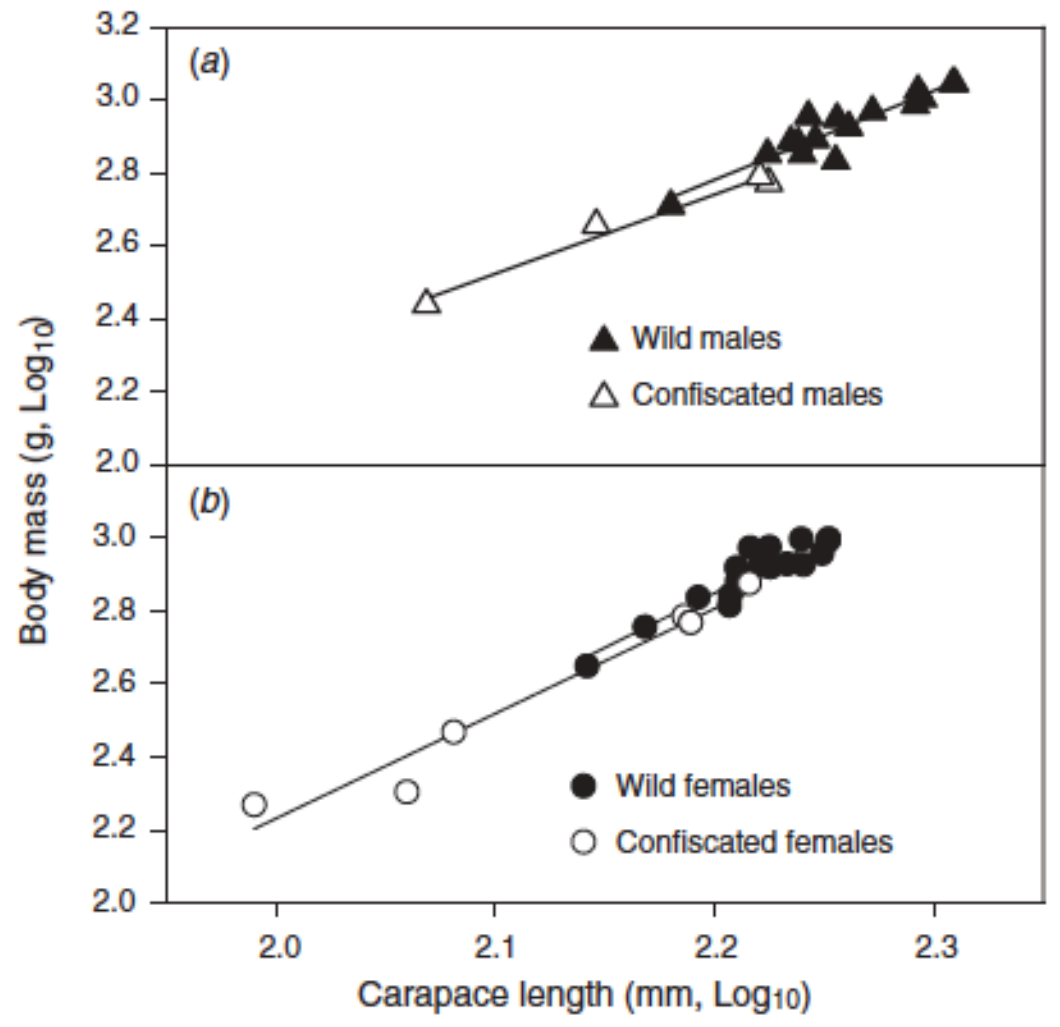

Fig. 1. Regressions of $\log _{10}$ body mass on $\log _{10}$ carapace length for $(a)$ male (triangles) and (b) female (circles) Chersina angulata in January-February 2001 (summer). All groups had similar slopes (ANCOVA $F_{3,45}=2.67$, $P=0.059)$, but elevations differed among groups $\left(F_{3,48}=22.88, P<10^{-6}\right)$. Wild females (solid circles) had significantly higher elevations than did all other groups, which did not differ from one another (Tukey and SNK post hoc tests). After correcting for carapace length, wild females had $\sim 100 \mathrm{~g}$ $(13 \% ; P<0.01)$ more mass than did confiscated females (open circles). 


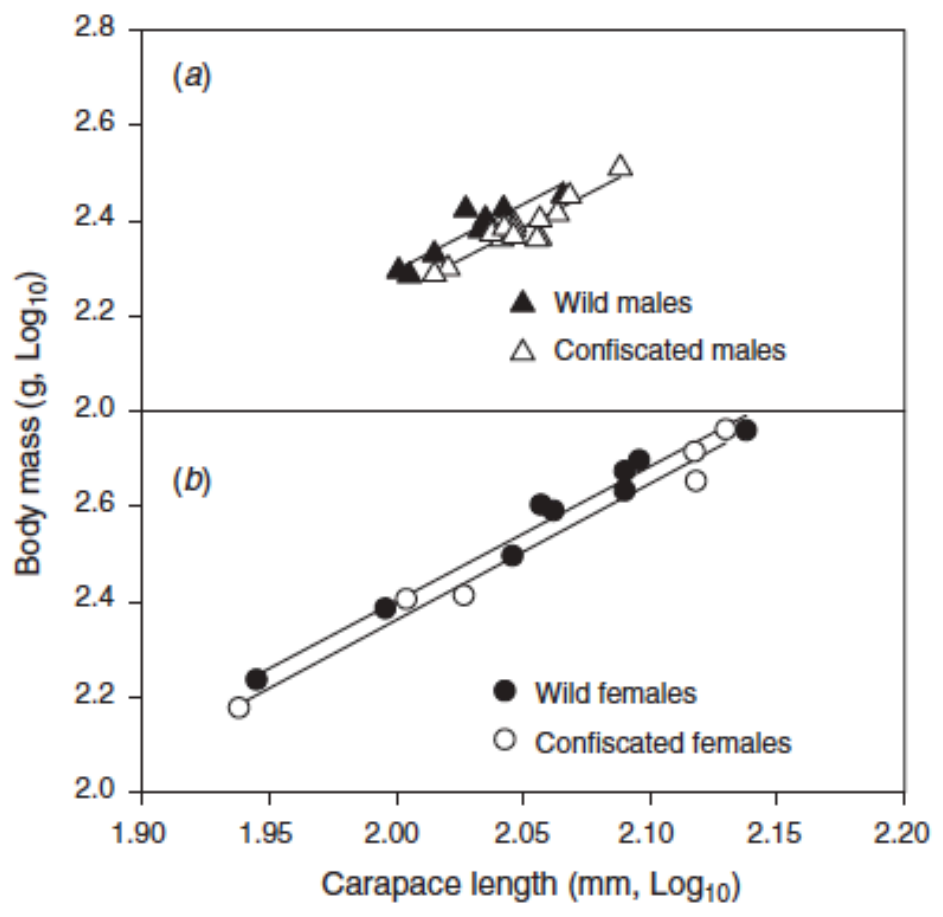

Fig. 2. Regressions of $\log _{10}$ body mass on $\log _{10}$ carapace length for wild (solid symbols) and confiscated (open symbols) (a) male (triangles) and (b) female (circles) Psammobates geometricus individuals in December 2000 and February 2001. Slopes didnot differ $\left(F_{3,32}=0.096\right.$ and $\left.P>0.96\right)$, whereas elevations did $\left(F_{3,35}=90.31, P<10^{-6}\right)$ among all groups (Tukey and SNK post hoc, $P<0.05)$. Wild and confiscated females differed by $28 \mathrm{~g}(8.2 \%$; $P<0.01)$. Wild and confiscated males differed by $28 \mathrm{~g}(10.5 \% ; P<0.0005)$. 


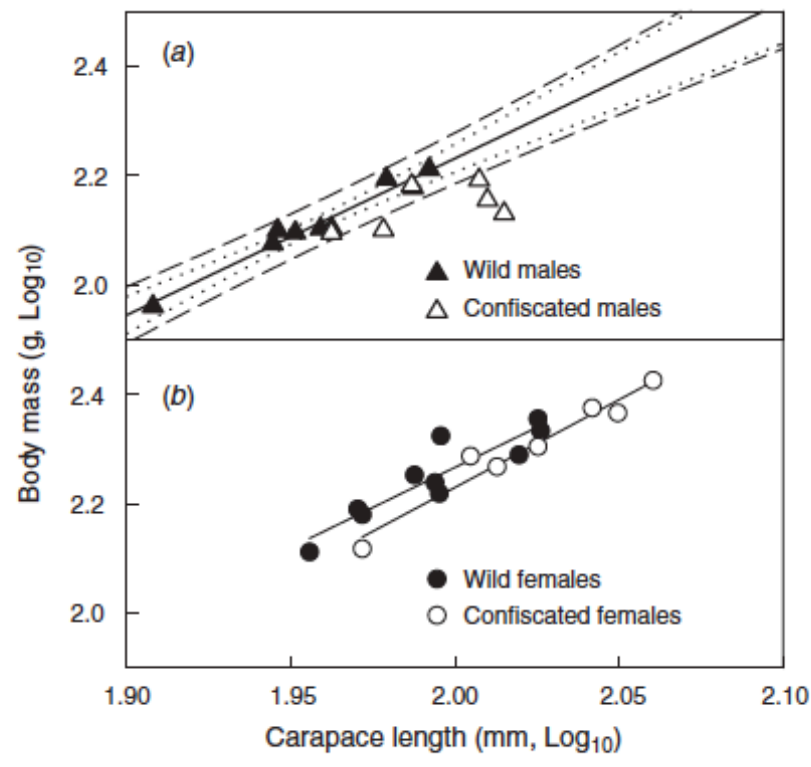

Fig. 3. Regressions of $\log _{10}$ body mass on $\log _{10}$ carapace length for $(a)$ male (triangles) and (b) female (circles) Homopus areolatus individuals. The wild-confiscate comparison for females identified equal slopes (ANCOVA: $\left.t_{14}=0.13, P>0.90\right)$ and different elevations $\left(t_{15}=2.15\right.$, $P=0.049)$, with wild females $15 \mathrm{~g}$ or $7.8 \%$ heavier $(P<0.05)$. For male confiscates, the regression was not significant $\left(F_{1,4}=2.09, P=0.22\right)$. However, all six points for male confiscates fell below the regression line (solid line) for wild males, five confiscate points fell below the lower $95 \%$ confidence limit (dotted line) for wild males, and four confiscate points fell beneath the lower $95 \%$ prediction interval (dashed line) for wild males. Confidence and prediction intervals for wild males were extended to the axes to evaluate confiscate values.

Table 1. MANCOVA $F$-statistics for $\log _{10}$ body mass $\left(\log _{10} \mathrm{M}, \mathrm{g}\right)$, haematocrit (Hct, \%) and haemoglobin concentration $\left(\mathrm{Hb}, \mathrm{g} \mathrm{dL}^{-1}\right)$, with $\log _{10} \mathrm{CL}(\mathrm{mm})$ as the covariate, for all tortoises and each species (Ca, Chersina angulata; Ha, Homopus areolatus; Pg, Psammobates geometricus)

Categorical effects included species (Sp), sex and wild-confiscated (W-C) status. Also, multiple regression $R^{2}$-values are indicated for $\log _{10} \mathrm{M}$, Hct and $\mathrm{Hb}$, with $\log _{10} \mathrm{CL}$ as the covariate. Corresponding $P$-values are as follows: ${ }^{1} P \leq 0.05,{ }^{2} P<0.01,{ }^{3} P<0.005,{ }^{4} P<0.001,{ }^{5} P<0.0005$, ${ }^{6} P<0.0001,{ }^{7} P<0.00005,{ }^{8} P<0.00001$ and ${ }^{9} P<<0.00001$. $F$-values without superscripts are not significant (n.s.; $P>0.05$ ). For species and $\mathrm{Sp} \times \mathrm{W}-\mathrm{C}$ interaction, d.f. $=6,200$. n.a., not applicable

\begin{tabular}{|c|c|c|c|c|}
\hline Parameter & All & $\mathrm{Ca}$ & $\mathrm{Pg}$ & $\mathrm{Ha}$ \\
\hline \multicolumn{5}{|c|}{ MANCOVA $F$-values } \\
\hline $\log _{10} C L$ & $417.4^{9}$ & $142.7^{9}$ & $304.6^{9}$ & $63.12^{9}$ \\
\hline Sex & $48.62^{9}$ & $6.886^{4}$ & $57.02^{9}$ & $7.802^{4}$ \\
\hline $\mathrm{W}-\mathrm{C}$ & $15.20^{9}$ & $7.150^{4}$ & $11.34^{7}$ & 4.517 \\
\hline Species & $26.33^{9}$ & n.a. & n.a. & n.a. \\
\hline $\mathrm{Sp} \times \mathrm{W}-\mathrm{C}$ & $4.169^{4}$ & n.a. & n.a. & n.a. \\
\hline d.f. & 3,100 & 3,38 & 3,31 & 3,25 \\
\hline \multicolumn{5}{|c|}{ Adjusted $R^{2}$, whole model } \\
\hline $\log _{10} M$ & $0.9887^{9}$ & $0.9532^{9}$ & $0.9718^{9}$ & $0.9158^{9}$ \\
\hline Het & $0.3052^{8}$ & $0.5000^{8}$ & n.s. & n.s. \\
\hline $\mathrm{Hb}$ & $0.2776^{8}$ & $0.4777^{8}$ & n.s. & n.s. \\
\hline d.f. & 12,102 & 4,40 & 4,33 & 4,27 \\
\hline
\end{tabular}




\section{Haematology}

MANCOVA results were consistent with univariate ANOVA (Fig. 4) for Hct and $\mathrm{Hb}$. Haematology values differed among $\mathrm{C}$. angulata groups, with values for wild animals exceeding those for confiscate animals (SNK post hoc results, $\mathrm{P}<0.05$ ) and male values exceeding female values (SNK, $\mathrm{P}<0.05)$. Confiscate female $\mathrm{C}$. angulata had lower Hct and $\mathrm{Hb}$ than did their wild counterparts, the lowest Hct values of all 12 groups (males and females of each species), and lower $\mathrm{Hb}$ than all P. geometricus groups (SNK, P < 0.05).

Among and within species, body size ( $\log _{10}$ CL) had strong effects on body mass (MANCOVA and multiple regression; Table 1). Also, haematological values were correlated positively to $\log _{10}$ CL for C. angulata and all animals. Sex and species tended to explain more variance than did the $\mathrm{W}-\mathrm{C}$ status. The relative effect of sex and the $\mathrm{W}-\mathrm{C}$ status varied among species, and seemed strongest for P. geometricus (P-value; Table 1). The interaction between species and the $\mathrm{W}-\mathrm{C}$ status 


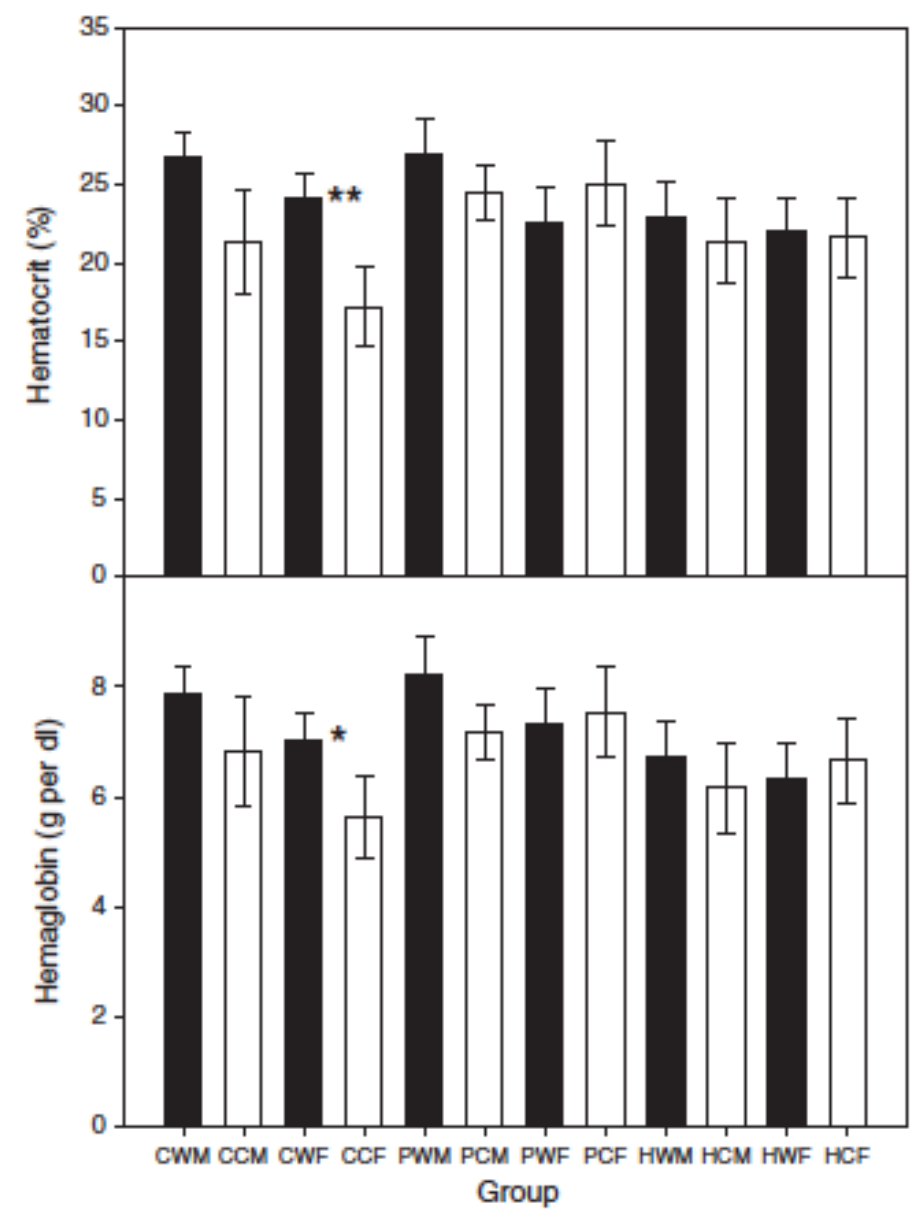

Fig. 4. Haematocrit ( $\mathrm{Hct}$ ) and haemoglobin $(\mathrm{Hb})$ concentration for groups evaluated in summer 2000-2001, Western Cape Province, South Africa. The group abbreviations represent, in sequence, the species $(\mathrm{C}=$ Chersina angulata, $P=$ Psammobates geometriaus and $\mathrm{H}=$ Homopus areolatus), wild (W, black bars) or confiscated (C, white bars), and male (M) or female (F) individuals. For instance, CCF represents $C$ angulata confiscated females. MANCOVA results for $C$. angulata indicated that wild animals had higher values than did confiscates $(P<0.005)$, male values exceeded female values $(P<0.005)$, and for females, $\mathrm{W}>\mathrm{C}$ for Het (** $P<0.001)$ and $\mathrm{Hb}\left({ }^{*} P<0.01\right)$.

The mean composite indices were negative for C. angulata, P. geometricus and all confiscates (Table 2), but not for $\mathrm{H}$. areolatus $\left(\mathrm{t}_{12}=1.36 \mathrm{P}=0.10\right)$, and were not affected by sex (two-way ANOVA, $\left.\mathrm{F}_{1,38}=0.42, \mathrm{P}=0.52\right)$, species $\left(\mathrm{F}_{2,38}=0.95, \mathrm{P}=0.40\right)$ or the interaction between sex and species $\left(\mathrm{F}_{2,3} 8=2.74, \mathrm{P}=0.077\right)$. However, individual indices varied considerably, from +4 to -6 , and equalled -6 for 4 of the 45 confiscates. The composite indices were correlated with classification probabilities for individual canonical scores, from discriminant analyses, for $\mathrm{P}$. geometricus and $\mathrm{H}$. areolatus, but not for C. angulata (Table 2). The strongest correlation was for P. geometricus, which had the largest sample size. may have resulted from (1) the sexual size dimorphism differing among species (males larger than females in C. angulata, but the reverse occurring for $\mathrm{P}$. geometricus and $\mathrm{H}$. areolatus) and (2) the sexual disparity in Hct and Hb in C. angulata (higher 
for males), but not in P. geometricus and H. areolatus (Fig. 4).

\section{Discriminant analysis}

All four variables ( $\left.\log _{10} \mathrm{CL}, \log _{10} \mathrm{BM}, \mathrm{Hct}, \mathrm{Hb}\right)$ were retained for discriminant analyses of the 12-group model, but not for each species (Table 3). Body size ( $\left.\log _{10} \mathrm{CL}, \log _{10} \mathrm{M}\right)$ frequently had higher F-values (Table 3), and higher ranked structure coefficients (Table 4), than did haematological variables among and within species. $\log _{10}$ CL entered earlier and was removed later than was $\log _{10} \mathrm{M}$ for $\mathrm{P}$. geometricus and $\mathrm{H}$. areolatus, but not for C. angulata.

Table 2. Mean, $\mathbf{9 5} \% \mathrm{CI}$ (confidence intervals) and range for composite indices, with one-tailed test comparison to zero (Student's $t$-test) Also indicated are Pearson $\left(r_{\mathrm{p}}\right)$ correlation coefficients between composite indices and classification probabilities (from discriminant scores) for confiscated adults. Correlations were significant at $P$-values as indicated in Table 1. Speciesincluded C. angulata $(\mathrm{Ca}, n=11), P$.geometricus $(\mathrm{Pg}, n=21)$ and $H$. areolatus $(\mathrm{Ha}, n=13)$

\begin{tabular}{lcccc}
\hline Parameter & All & Ca & Pg & Ha \\
\hline Mean & $-2.311^{9}$ & $-3.273^{4}$ & $-2.286^{3}$ & -1.539 \\
$95 \%$ CI & 0.982 & 1.592 & 1.419 & 2.475 \\
Range & -6 to 4 & -6 to 2 & -6 to 4 & -6 to 4 \\
$r_{\mathrm{p}}$ & $-0.4729^{2}$ & -0.07224 & $-0.5855^{2}$ & $-0.6271^{1}$ \\
\hline
\end{tabular}


Table 3. Discriminant analysis (DA) summaries for all species (all; 12 groups) and each species (Ca, Chersina angulata; $\mathrm{Ha}$, Homopus areolatus;

Pg, Psammobates geometricus)

Wilk's Lambda and canonical $R$ (Can $R$ ) had the same $F$-values. $P$-values are as indicated in Table 1. Interactions were not significant at $P \leq 0.05$. Statistics include Wilk's lambda and Can $R$ and their corresponding $P$-value for $\chi^{2}$ tests or $F$-tests for significance of variables $\log _{10} \mathrm{CL}, \log _{10} \mathrm{M}$, haemoglobin $(\mathrm{Hb})$, haematocrit (Hct), species and sex. The squared Mahalanobis distances $\left(D^{2}\right)$ indicate statistical distances $(P \leq 0.05)$ between wild and confiscated $(\mathrm{W}-\mathrm{C})$ animals for each sex in each species. The hit ratio, the overall percentage of cases classified correctly, was evaluated using Press's $Q$ statistic. The range brackets the percentage correct for each of the 12 groups (all 12, species $\times$ sex $\times \mathrm{W}-\mathrm{C}$ combinations) or two groups (all W-C, and $\mathrm{W}-\mathrm{C}$ for each species). The MC ratio is the maximum chance ratio. n.s., not significant

\begin{tabular}{lccccc}
\hline Parameter & All 12 & All W-C & Ca W-C & Pg W-C & Ha W-C \\
\hline Wilk's lambda & $0.01356^{9}$ & $0.6150^{9}$ & $0.3461^{9}$ & $0.4433^{6}$ & $0.5197^{6}$ \\
Can $R$ & 0.9362 & 0.6205 & 0.7974 & 0.7461 & 0.6930 \\
Log $_{10}$ CL & $34.91^{9}$ & $30.91^{9}$ & n.s. & $32.43^{8}$ & $24.28^{7}$ \\
Log $_{10}$ M & $32.89^{9}$ & $37.08^{9}$ & $22.16^{7}$ & $32.02^{8}$ & $14.06^{4}$ \\
Hb & $2.489^{2}$ & n.s. & $13.13^{4}$ & $4.326^{1}$ & n.s. \\
Hct & $3.357^{4}$ & $7.419^{2}$ & $17.59^{5}$ & n.s. & n.s. \\
Species & - & $19.77^{9}$ & - & - & - \\
Sex & - & $11.15^{3}$ & n.s. & $15.14^{5}$ & n.s. \\
d.f. & 11,100 & $1,108^{\text {A }}$ & 1,41 & 1,33 & 1,29 \\
$D^{2}$ W-C & Most W-C & $2.583^{9}$ & $9.064^{9}$ & $4.812^{7}$ & $3.592^{6}$ \\
Hit ratio (\%) & $73.9^{9}$ & $83.5^{9}$ & $93.3^{9}$ & $86.8^{8}$ & $81.3^{5}$ \\
Range & $14-100$ & $73-90$ & $73-100$ & $81-94$ & $69-89$ \\
MC ratio & 4.72 & 1.37 & 1.24 & 1.57 & 1.37 \\
\hline
\end{tabular}

A.f. $=2,108$ for species.

${ }^{\mathrm{B}} \mathrm{W}-\mathrm{C}$ group comparisons were significant $\left(D^{2}>3.68, F_{4,100}>4.66\right.$, $P<0.0018)$ except for Ha females $\left(F_{4,100}=1.86, D^{2}=1.86, P=0.12\right)$ and Pg females $\left(F_{4,100}=2.15, D^{2}=2.46, P=0.08\right)$. 
Table 4. Raw coefficients for 12-group (all 12) and two-group wild-confiscated (W-C) discriminant functions (all and species-specific functions)

Species $\times$ sex interactions were not significant (n.s.) or were not applicable (n.a., within each species). The first and second superscripts of the coefficients indicate the rank of the standardised coefficients and factor structurecoefficients, respectively.

The centroids are included for the $\mathrm{W}$ group and $\mathrm{C}$ group, as are the cutting scores to classify individual cases. Ca, Chersina angulata; $\mathrm{Ha}$, Homopus areolatus; $\mathrm{Hb}$, haemoglobin $\left(\mathrm{g} \mathrm{dL}^{-1}\right) ; \mathrm{Hct}$, haematocrit $(\%) ; \mathrm{Pg}$, Psammobates geometricus

\begin{tabular}{lcccccr}
\hline Parameter & \multicolumn{2}{c}{ All $12^{\mathrm{A}}$} & All W-C & Ca W-C & Pg W-C & Ha W-C \\
& Function 1 & Function 2 & & & & \\
\hline Intercept & 54.96 & 96.61 & -67.98 & 18.87 & -136.9 & 129.9 \\
$\log _{10}$ M & $1.056^{4,2}$ & $31.03^{1,3}$ & $-23.79^{1,1}$ & $-6.707^{3,1}$ & $-40.68^{1,3}$ & $21.20^{2,2}$ \\
$\log _{10}$ CL & $-27.81^{1,1}$ & $-83.71^{2,1}$ & $62.51^{2,3}$ & n.s. & $117.4^{2,4}$ & $-88.72^{1,1}$ \\
Het & $-0.1191^{3,3}$ & $0.04229^{3,4}$ & $-0.1206^{6,4}$ & $-0.5411^{1,3}$ & n.s. & n.s. \\
Hb & $0.4922^{2,4}$ & $-0.09813^{4,2}$ & n.s. & $-1.833^{2,4}$ & $-0.4598^{4,2}$ & n.s. \\
Sex - F & n.s. & n.s. & $0.7891^{4,6}$ & n.s. & $1.972^{3,1}$ & n.s. \\
Species - Ca & n.s. & n.s. & $-0.6385^{5,2}$ & n.a. & n.a. & n.a. \\
Species - Ha & n.s. & n.s. & $-1.355^{3,5}$ & n.a. & n.a. & n.a. \\
Eigenvalue & 7.098 & 3.911 & 0.6261 & 1.747 & 1.256 & 0.9241 \\
Cum. Prop. & 0.6039 & 0.9367 & & 1 & 1 & 1 \\
W centroid & & & 0.3076 & -0.7348 & -1.2122 & 0.7699 \\
C centroid & & & -0.4785 & 2.2713 & 0.9813 & -1.1252 \\
Cutting score & & & -0.1709 & 1.5365 & -0.2309 & -0.3553 \\
\hline
\end{tabular}

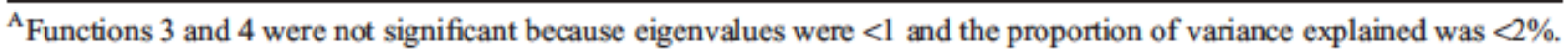

For the 12-group model, $\mathrm{D}^{2}$ discriminated all $\mathrm{W}-\mathrm{C}$ groups $(\mathrm{P}<0.05$, within each species and sex) except for $\mathrm{H}$. areolatus females and P. geometricus females (Table 3). When using species and sex as categorical variables of the model, all $\mathrm{W}-\mathrm{C}$ comparisons were significant $\left(\mathrm{F}_{4,100}>3.25 ; \mathrm{P}<0.015\right)$, except for female $\mathrm{H}$. areolatus $\left(\mathrm{F}_{4,100}=2.29, \mathrm{P}=\right.$ 0.065). Within each species, discrimination was strong (all $\mathrm{P}<0.025$, Table 3 ) among all four groups, confiscate males and females, wild males and females, except in C. angulata, where confiscate males and females did not differ $\left(\mathrm{F}_{2,40}=1.65, \mathrm{P}=0.21\right)$, and $\mathrm{P}$. geometricus, where confiscate and wild females did not differ $\left(\mathrm{F}_{3,32}=2.73, \mathrm{P}=0.060\right)$.

\section{Classification success}

The hit ratio indicated improved classification under the maximum chance criterion (MC ratio; Table 3) and Press's Q statistic (all $X^{2}{ }_{3}=126.6, \quad \mathrm{P}<10^{-6} ;$ individual species all $\left.X^{2_{2}} \geq 21.39, \mathrm{P} \leq 10^{-4}\right)$. However, classifications per group ranged from $14 \%$ to $100 \%$ in the 12-group analysis, and from $69 \%$ to $100 \%$ when sex (within species) or sex and species (all $\mathrm{W}-\mathrm{C}$ ) were used as categorical variables. Although MC ratios were lower within species than in the 12-group analysis, the latter hit ratio was the lowest. The use of species and sex as categorical variables reduced misclassifications $37 \%$ (from 30 for all 12, to 19 for all W-C). Haematological variables appeared weak for the $\mathrm{H}$. areolatus model, perhaps because of small sample sizes per group, and high variability within confiscates, particularly females (Fig. 4). 
For each discriminant analysis, misclassified cases did not differ from correctly classified cases for the four variables (ANOVA: all $F<2.14$ : d.f.1 $=4$, and d.f.2 $=27-110$ ). The exception was the 12-group classification, where $\mathrm{F}_{4,110}=2.98$ and $\mathrm{P}=0.022$; SNK post hoc showed misclassified CL were $20 \mathrm{~mm}$ (16\%) shorter, and their mass $140 \mathrm{~g}(40 \%)$ less, than for correctly classified animals. This may have been related to the species $\mathbf{x}$ sex interaction, such that body-size effects were not the most consistent discriminator, especially between $\mathrm{P}$. geometricus males and $\mathrm{H}$. areolatus females, which were similar in size. The smallest species, H. areolatus, had the most misclassifications (14, 44\%), compared with P. geometricus $(8,21 \%)$ and C. angulata $(8,18 \%)$. Sample size for $\mathrm{H}$. areolatus, especially males, was the smallest.

\section{Factor analysis, principal component analysis}

$\log _{10} \mathrm{M}$ and $\log _{10} \mathrm{CL}$ were highly correlated $\left(\mathrm{r} \geq 0.88, \mathrm{P}<<10^{-5}\right.$ for each species and all animals), as were $\mathrm{Hb}$ and $\mathrm{Hct}$ (all $\mathrm{r} \geq 0.81, \mathrm{P}<<10^{-5}$ ). Overall and in $\mathrm{C}$. angulata, $\mathrm{Hb}$ and Hct were also correlated with body size ( $\mathrm{r}=0.23-0.70 ; \mathrm{P}<0.05$ to $<<10^{-5}$, respectively). This did not occur in $\mathrm{H}$. areolatus, but Hct was inversely and weakly correlated with $\log _{10}$ $(\mathrm{r}=-0.33, \mathrm{P}<0.05)$.

$\mathrm{M}$ in P. geometricus As rotated, the two factors, size and haematology, explained much (9398\%) of the variance (Table 5). Each factor accounted for nearly half of the variation. Size was the first variate and haematology the second variate, except in C. angulata, where the order was reversed.

\section{Discussion}

Health assessments and their reference values are central to animal diagnostics for zoos, pets and wildlife physiology and epidemiology (Christopher et al. 1999; Bailey et al. 2000; Atkins et al. 2010; Ward et al. 2012), and can guide recovery of species vulnerable to diseases (e.g. United States Fish and Wildlife Service 1994; Sainsbury and Vaughan-Higgins 2012). Despite the lack of overt trauma or disease among confiscates, our quick analyses discriminated wild and confiscate tortoises, with likelihoods being from $\mathrm{P}<0.05$ to $\mathrm{P}$ $<10^{-6}$. These results provided powerful forensic evidence in the court of law, provided baseline information to guide ensuing care and disposition for individual tortoises, and illustrated the many merits of health assessments and their statistical analysis.

\section{Forensics and body of evidence}

The health assessments had many valuable forensic features (Anderson 1999; Cooper et al. 2009; Ogden et al. 2009) and were most useful in context of all evidence and statements. First, the methods were quick and portable, so we had results within a few days of the confiscation and submitted statistically summarised results to government officials in less than 1 month, a month before the poachers' plea. The species are easy to identify and 
are not endemic to KwaZulu-Natal, obviating delays and costs of more elaborate, yet sophisticated and powerful, analyses to identify species (e.g. Ogden et al. 2009).

Table 5. Factor loadings, Varimax normalised, for significant factors incorporating $\log _{10} \mathrm{M}, \log _{10} \mathrm{CL}$, haematocrit (Het, $\%$ ) and haemoglobin $\left(\mathrm{Hb}, \mathrm{g} \mathrm{dL}^{-1}\right)$, for all animals and each species (Ca, Chersina angulata; Ha, Homopus areolatus; $\mathrm{Pg}$, Psammobates geometricus)

Factor loadings of $\sim 0.35$ or higher were considered significant at $P=0.01$ (Hair et al. 1998). Factor significance was based on criteria for eigenvalues (explained variance (Expl. Var) of $>1$ ) and proportion of variance (Prp. Totl of $>0.1$ of total)

\begin{tabular}{lcccccccc}
\hline Parameter & \multicolumn{2}{c}{ All, $n=115$} & \multicolumn{2}{c}{ Ca, $n=45$} & \multicolumn{2}{c}{ Pg, $n=38$} & \multicolumn{2}{c}{$\mathrm{Hg}, n=32$} \\
& Factor 1 & Factor 2 & Factor 1 & Factor 2 & Factor 1 & Factor 2 & Factor 1 & Factor 2 \\
\hline $\log _{10}$ mass & 0.9845 & 0.1362 & 0.3353 & 0.9302 & 0.9647 & 0.1271 & 0.9751 & 0.08807 \\
$\log _{10}$ CL & 0.9865 & 0.1188 & 0.3930 & 0.9058 & 0.9670 & 0.06440 & 0.9742 & -0.09988 \\
$\mathrm{Hct}(\%)$ & 0.1064 & 0.9706 & 0.9209 & 0.3555 & -0.1973 & -0.9552 & -0.07600 & 0.9531 \\
$\mathrm{Hb}\left(\mathrm{g} \mathrm{dL}^{-1}\right)$ & 0.1445 & 0.9652 & 0.9161 & 0.3675 & -0.004948 & -0.9760 & 0.06472 & 0.9537 \\
Expl. Var & 1.975 & 1.906 & 1.954 & 1.947 & 1.905 & 1.885 & 1.910 & 1.836 \\
Prp. Totl & 0.4936 & 0.4766 & 0.4886 & 0.4868 & 0.4762 & 0.4713 & 0.4774 & 0.4589 \\
Total variance & & 0.9702 & & 0.9754 & & 0.9475 & 0.9363 \\
\hline
\end{tabular}

Second, we used well known, reliable methods and analytes, collected by the same people using the same equipment, and reference values for the same species, sexes and seasons (and week for C. angulata). These methods and physical results are also easy to convey impartially in a court of law, and easy to express in terms of likelihood (i.e. statistical probability), reinforcing forensic presentation in court (Anderson 1999; Ogden et al. 2009). Additionally, the corroboration of many types of results, that is body condition, haematology and composite indices for many groups, synergistically strengthened arguments against specific statements made by the poachers, a critical forensic value (Ogden et al. 2009).

The poachers were convicted using a body of evidence. They claimed to collect the tortoises in 2 days before trying to transport them internationally. If this timeline were correct, the confiscate health would have been indistinguishable from reference values. Their claim was rebutted repeatedly, via tests of many parameters and groups, with statistical probabilities of $\mathrm{P}<0.05$ to $\mathrm{P}<10^{-6}$. Furthermore, the poachers claimed that they, two naive European tourists, ignorant of the wildlife- traffic restrictions, 'strolled through the veld' in the dry season and in 2 days found 54 tortoises, including 23 individual P. geometricus, one of the most rare, cryptic and relictually distributed chelonian species. This is also highly unlikely given evidence that just a few weeks prior, 12 experienced surveyors could not find as many P. geometricus during 5 days of surveying preferred habitat of the largest population of $\mathrm{P}$. geometricus. Their claims were even less likely because it is very difficult to find all three species sympatrically. The poachers were convicted and fined, and because they held no permits for the wildlife, were also fined in KwaZulu-Natal (Western Cape Nature Conservation Board 2001). 
Although tortoises may excrete faeces and urine in large masses, it is unlikely they would excrete $8-13 \%$ of their body mass, and suffer haematological degradation, while poachers held them captive for a few days. Desiccation and starvation are long-term processes that require weeks to months (Henen 1994; Christopher et al. 1999), and were more likely to occur if the animals were caught and held by locals for a 2-day collection by the poachers. Desiccation and starvation were also consistent with the low haematological values and willingness of the confiscates to drink during our assessments. Low haematological values were not likely to be due to haemodilution, as if tortoises drank in the poachers' care, because drinking-induced haemodilution would increase body mass and condition, contradicting the strongest finding of our study.

The forensic application of health assessments may have been unique at the time, but the broad zoo and veterinary use of health assessments, and the mistreatment of poached wildlife in the massive, illegal wildlife trade mean that their forensic use may become more frequent. Reference ranges are not available for many species, but they are becoming more common and comprehensive (Christopher et al. 1999; Osborne et al. 2010; Ward et al. 2012). Recent validations of advanced analysers indicate that accurate, detailed plasmabiochemistry measurements are possible in remote field locations (Atkins et al. 2010). Those studies should help address species and analyte deficiencies in reference ranges, and clarify which analytes and parasite measurements are most valuable. Our univariate to multivariate analyses illustrated that four simple variables were powerful, but there may be circumstances when more sophisticated analyses and more powerful statistical analyses are prudent.

\section{Merits of univariate, bivariate and multivariate analyses}

Because univariate, bivariate and multivariate analyses each offer advantages, researchers will better understand their results with systematic data inspection and a combination of analyses. Univariate statistics were quick and easy to apply, understand and portray for the court. ANCOVA were simple, accurate, powerful, easy to convey and required close, systematic inspection and processing of the data (Zar 1999), so they provided a more detailed understanding than often occurs in multivariate statistics processed with advanced statistical software. The composite indices were quick to calculate for our preliminary report (Henen and Hofmeyr 2001) and enabled us to identify which individuals were most compromised.

However, the many groups, variables and effects of our complex data make repeated univariate analyses vulnerable to Type 1 Error (Zar 1999). Also, the variables lack independence, especially haematocrit and haemoglobin concentrations, so they may provide little unique variance or independent discriminatory power. Multivariate analyses capitalise on the large sample size and the extra variance and explanatory power provided by additional, statistically significant variables. In addition to determination of main effects (W vs C) by using ANCOVA, MANCOVA demonstrated the importance of species and sex. Discriminant analyses are probably the most powerful method to classify groups and 
individuals. The discriminant functions are also useful to classify animals in future studies. The all-species function could be applied to many other chelonian species; however, species-, sex- and season-specific discriminant functions would be more accurate (see also Atkins et al. 2010; Osborne et al. 2010; Ward et al. 2012).

Multivariate analyses added perspective and power. The statistical rigour and power of multivariate space quantified and ranked the main effects of body size, species, sex and $\mathrm{W}-\mathrm{C}$ status, demonstrating the need for species- and sex- specific reference ranges to distinguish $\mathrm{W}$ and $\mathrm{C}$ groups and individuals. Multivariate statistics (MANCOVA) also identified the species $\mathbf{x}$ sex interaction, so future studies must address species differences in sexual-size dimorphism and haematological variation between the sexes.

Although factor analysis suggested that there were two strong variates, namely, size and haematology, using all four variables was supported conceptually, by adding unique variance and explanatory power, and empirically. The empirical relationship of body mass to shell size was a critical indication of body condition in our ANCOVA, MANCOVA, multiple-regression and discriminant analyses. Furthermore, there were strong species differences in the relative importance of the fourvariables in the wild and confiscate discrimination. With judicious collection and analysis of health assessment data, we can enhance their value for forensics, animal husbandry, risk assessments and species recovery.

\section{Acknowledgements}

We are very grateful for the efforts of the South African Veterinary Services, South African Police Services and Ezemvelo-KZN-Wildlife in detecting poachers and transporting the confiscated tortoises to the Western Cape Province. We are also very grateful for the support and assistance of the Tygerberg Zoo (the late John Spence; Werner Fourie and Elton Decklar), CapeNature (Atherton de Villiers), Terry E. Christopher (USA) and Mosa Lesia (UWC) in processing tortoises at the Tygerberg Zoo. We are also very grateful for support from the Elandsberg Nature Reserve (the late Dale Parker; Elizabeth Parker and Mike Gregor), Voëlvlei Nature Reserve (Peter Viljoen; CapeNature), Dassen Island (Anton Wolfaardt, Johnny Witbooi, Johan Visagie and Leigh-Anne Wolfaardt; CapeNature) and West Coast National Park (Paul Sieben, South African National Parks Board). We are indebted to Martin Hendricks, Mandisa Mdala, Scott Ramsay, Quinton Joshua, Sarah Jarvis and Jens Oelbüttel for laboratory or field assistance. This research was authorised by the Western Cape Nature Conservation Board (Permits 176 and 923, 2000; and 280 and 1027, 2001) and by UWC's Research Ethics Committee. This research was supported by the National Research Foundation of South Africa (2039659), the Royal Society of London and the University of the Western Cape (96/10/15). 


\section{References}

Anderson, G. S. (1999). Wildlife forensic entomology: determining time of death in two illegally killed black bear cubs. Journal of Forensic Sciences 44, 856-859.

Atkins, A., Jacobson, E., Hernandez, J., Bolten, A. B., and Lu, X. (2010). Use of a portable point-of-care (Vetscan VS2) biochemical analyzer for measuring plasma biochemical levels in free-living loggerhead sea turtles (Caretta caretta). Journal of Zoo and Wildlife Medicine 41, 585-593. doi:10.1638/2009-0023.1

Bailey, T., Silvanose, C., Naldo, J., Combreau, O., Launay, F., Wernery, U., Kinne, J., Gough, R., and Manvell, R. (2000). Health considerations of the rehabilitation of illegally traded houbara bustards Chlamydotis undulata macqueenii in the Middle East. Oryx 34, 325334 .

Berry, K. H., and Christopher, M. M. (2001). Guidelines for the field evaluation of desert tortoise health and disease. Journal of Wildlife Diseases 373, 427-450.

Christopher, M. M., Berry, K. H., Wallis, I. R., Nagy, K. A., Henen, B. T., and Peterson, C. C. (1999). Reference intervals and physiologic alterations in hematologic and biochemical values of free-ranging desert tortoises in the Mojave Desert. Journal of Wildlife Diseases 352, 212-238.

Cooper, J. E., Cooper, M. E., and Budgen, P. (2009). Wildlife crime scene investigation: techniques, tools and technology. Endangered Species Research 9, 229-238. doi:10.3354/esroo204

EUROPOL (2011). 'EU Organised Crime Assessment.' (Europol Analysis and Knowledge Unit: The Hague, Netherlands.)

Fidenci, P., and Maran, J. (2009). Illegal domestic trade of the Philippine Forest Turtle (Siebenrockiella leytensis) in the Philippines. TurtleLog 3, 1-3. Available at http://www.iucn-tftsg.org/turtlelog_online_newsletter/tlnoo3/ [Verified 27 January 2013].

Flint, M., Morton, J. M., Limpus, C. J., Patterson-Kane, J. C., Murray, P. J., and Mills, P. C. (2010). Development and application of biochemical and haematological reference intervals to identify unhealthy green sea turtles (Chelonia mydas). Veterinary Journal 185, 299-304. doi:10.1016/j. tvjl.2009.06.011

Hair, J. F., Jr, Anderson, R. E., Tatham, R. L., and Black, W. C. (1998). 'Multivariate Data Analysis.' 5th edn. (Prentice Hall: Upper Saddle River, NJ.)

Henen, B. T. (1994). Seasonal and annual energy and water budgets of female desert tortoises (Xerobates agassizii) at Goffs, California. Ph.D. Dissertation, University of California, Los Angeles, CA.

Henen, B. T., and Hofmeyr, M. D. (2001). Confiscated South African tortoises: a preliminary health assessment for the Western Cape Nature Conservation Board and the Tygerberg Zoo. Chelonian Biodiversity and Conservation - Southern Africa, University of the Western Cape, Bellville, South Africa.

Jacobson, E. R., Schumacher, J., and Green, M. (1992). Field and clinical techniques for sampling and handling blood for hematologic and selected biochemical determinations in the desert tortoise, Xerobates agassizii. Copeia 1992, 237-241. doi:10.2307/1446559 
Leuteritz, T.E.J., and Weissgold, B. (2013). Shell-shocked: trade in turtles threatens species. Fish and Wildlife News Winter 2013, 17

Ogden, R., Dawnay, N., and McEwing, R. (2009). Wildlife DNA forensics - bridging the gap between conservation genetics and law enforcement. Endangered Species Research 9, 179-195. doi:10.3354/esroo144

Osborne, A. G., Jacobson, E. R., Bresette, M. J., Singewald, D. A., Scarpino, R. A., Bolton, A. B., and Lu, X. (2010). Reference intervals and relationships between health status, carapace length, body mass, and water temperature and concentrations of plasma total protein and protein electrophoretogram fractions in Atlantic loggerhead sea turtles and green turtles. Journal of the American Veterinarian Medical Association 237, 561-567. doi:10.2460/javma.237.5.561

Real, J., Mañosa, S., and Muñoz, E. (2000). Trichomoniasis in a Bonelli's eagle population in Spain. Journal of Wildlife Diseases 36, 64-70. Sainsbury, A. W., and Vaughan-Higgins, R. J. (2012). Analyzing disease risks associated with translocations. Conservation Biology 26, 442-452. doi:10.1111/j.1523-1739.2012.01839.x

Spicer, J. (2005). 'Making Sense of Multivariate Data Analysis.' (Sage Publications: Thousand Oaks, CA.)

Swimmer, J. Y. (2000). Biochemical responses to fibropapilloma and captivity in the green turtle. Journal of Wildlife Diseases 36, 102-110.

TRAFFIC (2004). Seizures and prosecutions. TRAFFIC Bulletin 20, 1-43.

TRAFFIC (2010). Experts to establish Wildlife Forensics Network. Traffic

Wildlife Trade News. Available at http://www.traffic.org/home [Verified 21 January 2013].

United States Fish and Wildlife Service (1994). 'Desert Tortoise (Mojave Population) Recovery Plan.' (United States Fish and Wildlife Service: Portland, OR.)

Ward, J. L., Hall, K., Christian, L. S., and Lewbart, G. A. (2012). Plasma biochemistry and condition of confiscated hatchling pig-nosed turtles (Carettochelys insculpta). Herpetological Conservation and Biology 7, 38-45.

Western Cape Nature Conservation Board (2001). A major breakthrough for environmental law enforcement. Western Cape Nature Conservation Board Media Release, 31 August 2001, Jonkershoek, South Africa.

Wyler, L. S., and Sheikh, P. A. (2008). 'International Illegal Trade in Wildlife: Threats and US Policy.' (Congressional Research Service, The Library of Congress: Washington, DC.)

Zar, J. H. (1999). 'Biostatistical Analysis.' 4th edn. (Prentice Hall: Upper Saddle River, NJ.) 